DOI 10.18551/rjoas.2019-08.12

\title{
ANALYSIS OF THE SOCIO-ECONOMIC CHARACTERISTICS OF FISH TRADERS IN BASE OEBA FISH LANDING AT KUPANG CITY, INDONESIA
}

\author{
Majid Abdul \\ Study Program of Agribusiness, Faculty of Fisheries, University of Muhammadiyah, \\ Kupang, Indonesia \\ E-mail: abdulmajid.umk.1961@gmail.com
}

\begin{abstract}
This research was conducted to understand the socio-economic characteristic of fish traders in fish landing bases, Oeba Kupang. To understand these characters, the mixed quantitative and qualitative data were applied. To get the data needed, a serial data collection such as field survey, in-depth interviews, focus group discussions (FGD) and observation activities were employed. the respondents using purposive sampling method as many as 70 respondents were successfully conducted. The results show that socioeconomic characteristics of these fish traders inshore areas characteristic with the average quality of low human resources. Generally, their jobs were hereditary as fish traders with an average of low educational background. Therefore, their incomes were still largely under the district minimum wage. However, to support their main incomes, the fish traders have other part-time jobs ranging from small trades, agriculture, and other livelihoods.
\end{abstract}

\section{KEY WORDS}

Socio-economic development, fish traders characteristics, Kupang area, public service.

Indonesia is the largest archipelagos in the world with an area of sea that can be managed by 5.8 million. It can be used for fishing and other coastal economic activities. The weakness of the fishery areas is a classical issue becoming a serious problem in realizing sustainable fisheries sector (Bappenas, 2014). Kupang city as the capital of East Nusa Tenggara province is an urban coastal area. The town is situated in the southern region of Indonesia has 51 villages where 16 villages located on the coast. Kota Kupang is an island city that most of the population live in coastal areas. Aquaculture production greatly affects the lives of coastal communities are mostly fishermen. This will affect the social-ecological resource-based coastal communities, especially fisheries. Coastal communities depending on the use and management of fisheries resources. They are a major component of the maritime community construction Indonesia (Kusnadi, 2009).

The population density and in line with the development of pressure on the environment. Coastal communities have distinct social characteristics that are different from the people who live on the mainland. One needs that are absolutely necessary to advance the fishing activity is the fishing port of adequate infrastructure. Fish merchant community life can be seen from the city Kupang social and economic aspects. Socially can be seen from the level of education, institutions, and organizations. On the economic aspects can be seen from the possession of the goods, livelihood, income, as well as venture capital (Dharmawan, 2008). Condition social economy fish traders in Fish Landing Base-related activities of production, distribution, and consumption. The role of fish trade can obscure more job opportunities in big scales and the availability of community needs. The fish trade in this study are those people who do fish trade for their living that sell fish directly to consumers. Therefore, the purpose of this research is to understand the social-economical Fish traders in the fish trading area in Oeba, Kupang.

\section{METHODS OF RESEARCH}

The research location was Fish Landing Base Oeba, Kupang, East Nusa Tenggara. The study was conducted from March to May 2019. The quantitative methods supported by 
qualitative data was used through surveys, in-depth interviews, focus group discussion (FGD) and observation. The respondents were taken purposely sampling method as many as 70 respondents. Quantitative data were analyzed by the cross-tabulation form of diagrams and analyzed descriptively. Qualitative analysis was performed with data reduction, data presentation, and conclusion. To avoid data and interpretation errors are also used triangulation method where the data obtained from an informant who confirmed the informants.

\section{RESULTS AND DISCUSSION}

Kupang has an area of $180.27 \mathrm{~km}^{2}$, in 2017 as many as 33.05 percent of the population of the city of Kupang live in coastal areas with a population density of 8773 inhabitants per km2. The high number of residents in the city of Kupang one of which was contributed by migration. Most of them are from South Central Timor district, Kupang and Rote Ndao district. Data in the last five years (2010-2015), the migration to Kupang reached 53042 persons or $15 \%$ of the population. Kota Kupang communities in coastal areas can not be separated from the dependence of the natural resources of the sea. According to BPS (2018) the number of households fishery sea fishery Kota Kupang for 1471 households, fishing fleets as much as 1735 units with capture fisheries production amounted to 25274 tonnes. This significant growth shows migration social and cultural conditions that both ethnically and religiously diverse. Increased population density impact also on the high levels of unemployment and poverty (BPS 2018).

The density of the population in coastal areas with the middle to lower economic level and environmental stress on urban development shows that Kupang City is very vulnerable to environmental changes. The number of open unemployment in 2017 was 22442 people with an unemployment rate of 12.5 percent. An increase of 1.34 percent compared to the previous year. The number of underprivileged families in 2015 was 4682 . The poor population in Kota Kupang in 2017 amounted to 9.81 percent with a poverty line of Rp 504 179. The Human Development Index (HDI) in 2017 was 78.25 with a life expectancy of 68.58 years and real per capita expenditure of $\mathrm{Rp} 13028$. The coastal community business of Kota Kupang moved in the sector the average quality of human resources is still low.

Generally, they are involved in fishing effort to be hereditary and only rely on physical abilities, mostly fishermen, fishmongers and fish farmers. Development, human activities and the effects of physical factors contributing to sea beach damage in Kupang. Although the vulnerability of the coast and the environment in the bay mussel is low, the trend continues coast damage (DKP, 2007). Not only bay area in Kupang City but also it came under pressure due to development and settlement. According to Sunarto (2016) damage in Kupang Bay beach caused by land clearing for farms, fishery activities, the process of erosion residential natural and wild. The result is a vast reduction in coastal mangrove Kota Kupang during the years 1999-2013 were reached 37 percent (Siubelan et. al., 2015). In addition, marine sand and gravel mining, massive development in a commensurate beach, making coral reefs and mangrove damage more increase the development challenges in Kupang.

The development of coastal areas Kupang began at the entry of the Dutch colonial in Kota Kupang (Baun, 2008). The Dutch government was to build the port in the village of Lai Lai Bessi Kopan the entrance to trade in Kupang. The rapid economic development of urbanization makes Kupang destination for surrounding areas. Fish Landing Base (PPI) Oeba starts operation since the issuance of the Decree of the Head of Department of Marine and Fisheries of East Nusa Tenggara province. During its development, development of fishing ports done gradually by various means of support such as landing facilities, the provision of fuel, ship repair and other places. The existence of Fish Landing Base Oeba become centers where the fishing communities are directed to supporting the activities of local fishermen and fishermen entrants. Status of Fish Landing Base (PPI) Oeba is under the Regional Technical Implementation Unit (UPTD) and under the Marine and Fisheries Agency of East Nusa Tenggara. Fish Landing Base (PPI) PPI manager Oeba has its own head of 
which were previously still subordinated to the Head of Department of Marine and Fisheries, East Nusa Tenggara. Socio-economic portrait fish traders will be based on education, experience, income, and employment.

The level of education is an education/ high school have been followed by the respondent. The education level of the respondents was divided into three categories, elementary school/ not graduated, junior high, high school and college. The analysis showed the majority of respondents' education only finished primary school/ not completed (46\%).

Table 1 - The number and percentage of respondents by education level

\begin{tabular}{llll}
\hline & Level of education & $\mathrm{N}$ & $\%$ \\
\hline Primary School/ not completed & 32 & 46 \\
Secondary School & 23 & 33 \\
High School & 13 & 18 \\
Diploma & 2 & 3 \\
College/ University & 0 & 0 \\
Total & 70 & 100 \\
\hline
\end{tabular}

The quality of the fishing resources (HR) in Kota Sabang fishermen still low with an average level of education at the primary level. This condition is a consequence of the low number of educational facilities as well as its distribution is uneven. Economic demands and difficulties in finding employment opportunities make many fish merchants with a low level of education quality.

Revenue in the three villages strongly influenced research location fishery activities. Fishery becomes the largest source of income for households in the city of Kupang. It locates on the island and the coast and very close to the waters rich with marine resources makes almost all work as fishermen or fish traders. Revenue fish traders are quite varied. Revenue fish traders are the difference between revenues and costs of production. Revenue sources of income in the study area derived from the catch at sea and additionally from a second job.

Table 2 - Number and percentage of respondents based on the amount of revenue

\begin{tabular}{ccc}
\hline Income are fishmongers & $\mathrm{n}$ & $\%$ \\
\hline$<1793.298$ & 58 & 83 \\
$>1793.298$ & 12 & 17 \\
total & 70 & 100 \\
\hline
\end{tabular}

Source: Primary Data, 2018.

The Government of East Nusa Tenggara (NTT) decided workers minimum wage (UMP) for 2019 in the amount of Rp 1,793,298. UMP in 2019 increased by $8.03 \%$ from Rp1,660.000 in 2018, The results of the analysis of the majority of respondents have an income below the MSEs. Low-income levels caused by few things in between the weather in the west season the fishermen not to fish due to unfavorable natural conditions. In addition, fishmongers recognize a decline in revenue from the fisheries sector in the last few years. Revenue fish merchant location research depends on the results of the total fishing activities.

Every fish seller had a different experience when fishing and trading. Old fishing experience is becoming fishmongers calculated in units of time (years) since it first became a fish seller until the study was conducted. The analysis showed that the experience of the respondents in the study site is dominated span of $21-30$ years (49\%).

Table 3 - Number and Percentage of Respondents Based on Experience into fishmonger

\begin{tabular}{ccc}
\hline Experience as fishmongers & $\mathrm{N}$ & $\%$ \\
\hline$<10$ years & 13 & 19 \\
$10-20$ years & 15 & 21 \\
$21-30$ years & 34 & 49 \\
$>$ 30 years & 8 & 11 \\
Total & 70 & 100 \\
\hline
\end{tabular}

Source: Primary Data, 2018. 
The longer a person works as a fish merchant will affect knowledge about coastal environmental conditions and market conditions. The experience became fish traders often be decisive in making adjustments to the price.

The main work has regularly performed the activity of a person to meet their needs for family income. The main livelihood of fish traders still relies on the sector marine and fishery. The results of the analysis show that the whole main job is fishmongers (100\%). While another part-time job is a job done by someone to support and increase his family's income. Based on data analysis, it was found that the majority of the work at a second job community fishing is as breeder $21(30 \%)$. Overall the fish traders have part-time job diverse. The parttime job mostly is done alone and together with the hiring of community members. Part-time jobs they work at all outside the fisheries sector such as farming, gardening, trade, workers and farmers.

Table 4 - Percentage of the Main job and a Part-time Job

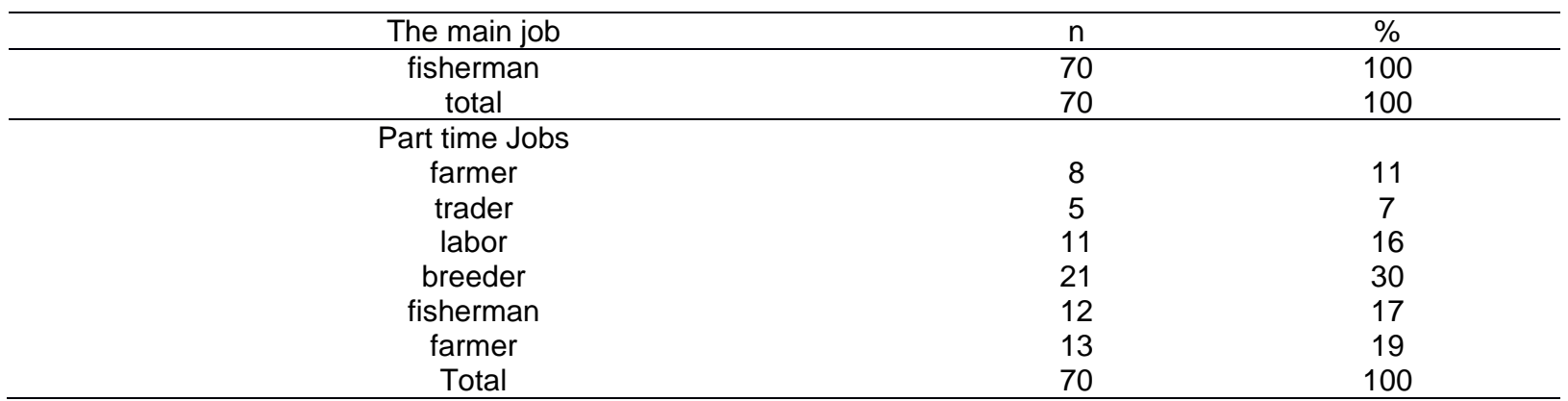

Source: Primary Data, 2018.

\section{CONCLUSION}

Most of the socio-economic activities of Kupang communities are in the coastal and fishery sectors. Kota Kupang coastal communities and fisheries average is still the low quality of human resources. Generally, the fishing to be passed down to a fish merchant. Education of fish traders was low that resulting in revenue fishmongers most of the time is still below minimum wage district. However, fish traders also have jobs in fish byproducts in trade and agriculture.

\section{REFERENCES}

1. Badan Pusat Statistik. 2018. Kota Kupang dalam Angka 2018. Kupang (ID): Badan Pusat Statistik Kota Kupang.

2. Badan Pusat Statistik. 2018. Provinsi Nusa Tenggara Timur Dalam Angka 2018. Kupang (ID): Badan Pusat Statistik Nusa Tenggara Timur.

3. Bappenas, 2014 Kajian Strategy pengelolaan perikanan berkelanjutan. Direktorat kelautan and perikanan, Jakarta, Indonesia.p.5-130

4. Baun PI. 2008. Kajian Pengembangan Pemanfaatan Ruang Terbangun di Kawasan Pesisir Kota Kupang [Tesis]. Semarang (ID): Universitas Diponegoro.

5. Dharmawan AH. 2007. Dinamika Sosio-Ekologi Pedesaan: Perspektif and Pertautan Keilmuan Ekologi Manusia, Sosiologi Lingkungan and Ekologi Politik. Sodality.1(1): 1-40

6. Kusnadi. 2009. Keberdayaan Nelayan and Dinamika Ekonomi Pesisir. Pusat Penelitian Wilayah Pesisir and Pulau-Pulau Kecil. Lembaga Penelitian Universitas Jember. $152 \mathrm{hlm}$.

7. Satria A. 2015. Pengantar Sosiologi Masyarakat Pesisir. Bogor (ID): Yayasan Pustaka Obor Indonesia.

8. Siubelan YC, Murtilaksono K, Lubis DP. 2015. Dinamika Keruangan Pesisir Kota Kupang Provinsi Nusa Tenggara Timur. JPSL. 5(1): 71-79. doi:10.29244/jpsl.5.1.71.

9. Sunarto. 2016. Konservasi Pantai Teluk Kupang Nusa Tenggara Timur. MGI. 15(1): 83100. doi:10.22146/mgi.13210. 